\title{
Knowledge management behaviors in venture capital crossroads: a comparison between IVC and CVC ambidexterity
}

\section{Matteo Rossi, Giuseppe Festa, Armando Papa, Ashutosh Kolte and Rossana Piccolo}

\begin{abstract}
Purpose - Institutional venture capitalists (IVCS) and corporate venture capitalists (CVCS) deploy analogous activities but adopt different approaches to financing innovation and value creation for venture-backed firms. Thus, this paper aims to investigate their potential ambidexterity as a result of knowledge management (KM) strategies and processes.

Design/methodology/approach - After a focused literature review showing evidence of KM behaviors as a source of potential ambidexterity for IVCs and CVCs, descriptive, inferential and discriminant analyses on the 15 most active IVCs and CVCs in the world in 2019 are presented. Correlations between numbers of deals, prevailing entrepreneurial intensity and potential ambidexterity are investigated.

Findings - Specific differences are analyzed from a KM perspective, revealing that the number/ percentage of operations per round can result as a misleading criterion of knowledge accumulation. Finally, a theoretical model for ambidexterity for venture capitalists is developed.

Originality/value - The study shows that IVCs act with greater investment capacity because of their organizational structure and purpose and focus on financial goals; moreover, they are ambidextrous, although their exploration may more frequently entail exploitation than "real" exploration. CVCs tend to invest in sectors related to their core business, coherent with their strategic purpose and more oriented with KM strategies for accumulating intellectual capital.
\end{abstract}

Keywords Ambidexterity, Knowledge management, Venture capital, Corporate venture capital, Knowledge accumulation, Institutional venture capital

Paper type Research paper

\section{Introduction}

Scholars have identified at least four waves of institutional venture capital (IVC) and corporate venture capital (CVC) (Dushnitsky, 2012): seed (1960-1970), consolidation (1980), boom (1990-2000) and rethinking (present). The history of IVC and CVC has been marked by periods of rapid growth and decline: at the turn of the 21st century, as noted above, the rethinking wave appeared, evolving the first vision of CVC as an investment vehicle for firms born in the 1960s (Rossi et al., 2017).

Over the past few years, CVC has been on the rise: as Boston Consulting Group has shown (2018), the percentage of CVC investments - as part of more general venture capital (VC) investments - grew from 20\% to 26\% over six years. In the same period from 2012 to 2017 , the total amount of invested capital increased from $€ 50 \mathrm{bn}$ to $€ 147 \mathrm{bn}$ with a compound annual growth rate of $31 \%$ (Figure 1).

Although IVC and CVC present similar profiles, they naturally exhibit relevant differences: they may diverge in their purpose, organization, compensation and support of portfolio firms (Gompers and Lerner, 2000).
(Information about the authors can be found at the end of this article.)

Received 2 May 2020 Revised 12 July 2020 Accepted 11 August 2020

(c) Matteo Rossi,

Giuseppe Festa,

Armando Papa, Ashutosh Kolte and Rossana Piccolo.

Published by Emerald

Publishing Limited. This article is published under the Creative Commons Attribution (CC BY 4.0) licence. Anyone may reproduce, distribute, translate and create derivative works of this article (for both commercial and non-commercial purposes), subject to full attribution to the original publication and authors. The full terms of this licence may be seen at http://creativecommons.org/ licences/by/4.0/legalcode

The authors declare that the paper is compliant with ethical standards and that they have no conflicts of interest.

The article is based on the study funded by the Basic Research Program of the National Research University Higher School of Economics (HSE) and by the Russian Academic Excellence Project '5-100'. 


\section{Figure 1 CVC investments from 2012 to 2017}

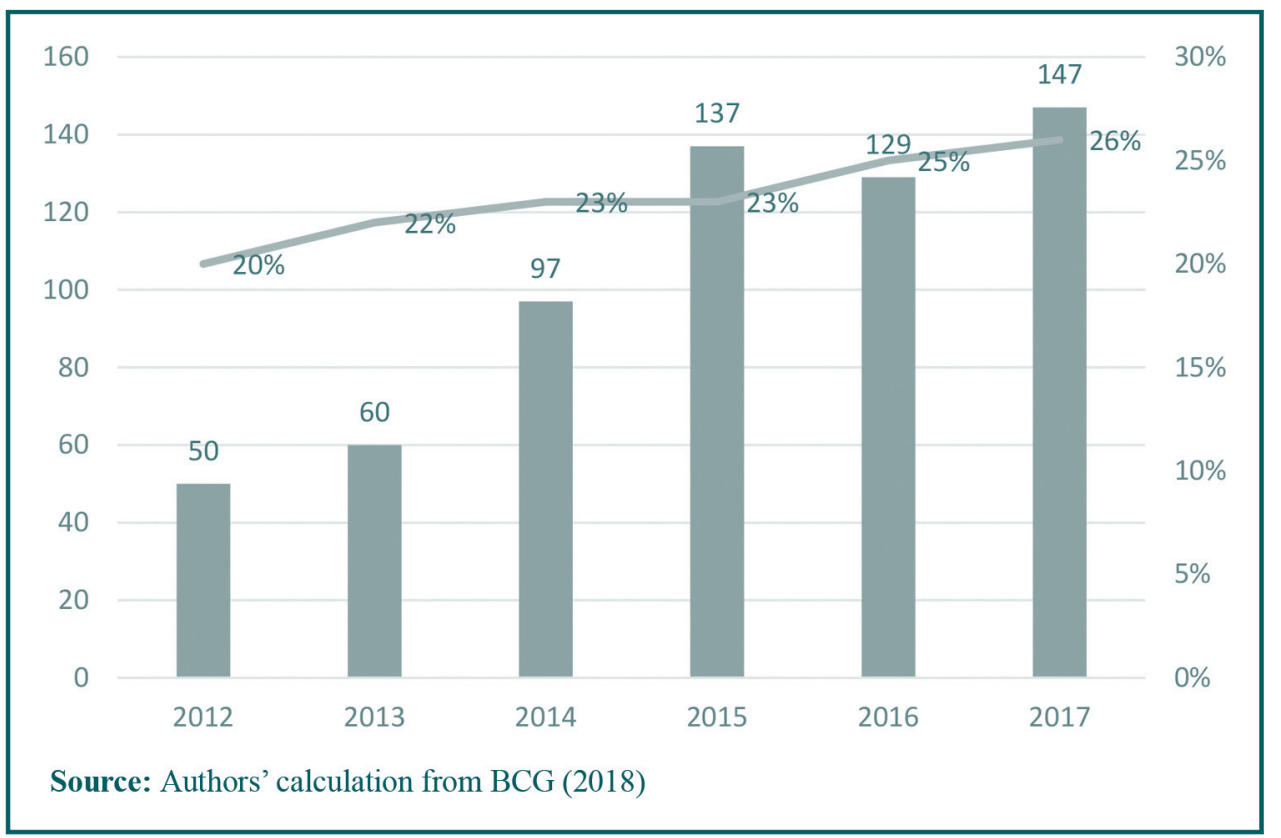

VC generally involves medium- to long-term investment in exchange for an equity stake in a company (Dagogo and Ollor, 2009) as a professionally managed fund of equity capital (Hisrich and Peters, 1998). In this respect, IVCs are independent pools of capital focused on equity or equity-linked investments in high-growth companies (Gompers and Lerner, 2001; Lerner, 2009; Rossi, 2015).

CVC covers an extensive variety of equity investments directly exercised by a corporation or its investment unit in high-potential firms: these operations can be considered "[...] equity-linked investments in start-up companies, executed by an intermediary owned and controlled by a nonfinancial corporation" (Maula et al., 2003, p. 119). The range of models is as diverse as the types of corporations involved.

Basically, IVC tends to pursue strictly economic aims (with a main focus on financial capital) while CVC rather involves a combination of strategic and economic aims likely (more) focused on exploring, embedding and exploiting knowledge and with a main/complementary/supplementary focus on intellectual capital (IC). In this research, the main differences between IVCs and CVCs are investigated with a specific emphasis on their ambidexterity to develop a theoretical framework describing potential impacts on VC ambidexterity derived from a knowledge management (KM) approach (Denford, 2013; Del Giudice et al., 2017a; Ramachandran et al., 2019).

The paper is organized as follows. Section 2 presents a review of the scientific literature comparing IVC to CVC with a subsequent focus on VC ambidexterity through the lens of KM. Section 3 describes the analysis methods used, and a discussion of results is provided in Section 4. Section 5 discusses the present study's limitation and avenues for future research. Conclusions and theoretical and practical implications are presented in Sections 7 and 8, respectively.

\section{Literature review}

\subsection{Institutional venture capitalist and corporate venture capitalist: nature, purpose and knowledge capacity comparisons}

Finance for innovative firms involves a large number of equity investors from public and private funds (Alvarez-Garrido and Dushnitsky, 2016; Blomkvist et al., 2016; Rossi and 
Martini, 2019). Not all investors pursue the same goals and have the same involvement in the deployment of their strategies.

Despite the popularity of IVC and CVC, scientific work systematically comparing them has been limited. After executing several queries through the most prominent scientific databases, only a few papers were found to adopt a strictly comparative approach as shown in Table 1.

Early empirical works on differences between IVC and CVC include McNally (1995) and Maula and Murray (2002). McNally (1995) concluded that:

CVC can provide more than just finance for investee companies. For direct investees the decision to specifically seek direct CVC finance largely reflects the belief that this form of investment has the potential to provide them with tangible and intangible value-added benefits in addition to financemplicit reference to IC performance.

Maula and Murray (2002) found that IVCs are better able to help the founders of high-tech firms transform their start-ups into viable companies mainly through additional financing, strategy development and key executive recruitment while CVCs play a stronger role in enhancing the public credibility of firms; attracting customers, suppliers and partners; and supporting technological development. The authors conclude that IVCs and CVCs have different, complementary value-added profiles, particularly in terms of knowledge assets: young firms can benefit from attracting both types of investors.

Maula et al. (2005, p. 3) demonstrated that "[...] the value-adding contributions of corporate venture capital and independent venture capital investors are different both in their origins and in their consequences." IVCs "[...]seem to better satisfy the needs of entrepreneurs when assisting with arranging finance, recruiting key employees, advising on competition and developing the organizational resources of the growing enterprise" while CVCs seem to be more effective at "[...] attracting foreign customers and providing advice on the technologies employed by the portfolio firms" (16), providing further substantial support for the results of their previous studies.

Hellmann (2002) explored why some VCs pursue financial gains while others are also interested in strategic objectives considering that VC markets are characterized for "[...] the entry of a large diversity of new investor types, such as corporations, banks, and other established organizations" (p. 304). It is emphasized that "[...] the fundamental difference between various types of venture investors is central to an understanding of entrepreneurial finance" (p. 304).

Dushnitsky and Lenox (2006) found a positive relationship between CVC and firm value creation that:

[...] is greatest within the devices, semiconductor, and computer sectors. Moreover, the contribution of corporate venture capital investment to firm value is greater when firms explicitly pursue CVC to harness entrepreneurial inventions. Thus, variance in CVC performance may be best explained by differences in the underlying objectives of the programs" (p. 754).

Table 1 Main studies on IVC - CVC comparison

Aim of the research Articles

Backed firm performance

Exit strategy

IVC and CVC McNally (1995), Maula and Murray (2002); Maula et al. (2005), Fulghieri and Seviril (2009); Dushnitsky and Shapira (2010), Chemmanur et al. (2014); Alvarez-Garrido and Dushnitsky (2016) Guo et al. (2011), Hahn and Kang (2017) purpose Hellmann (2002), Dushnitsky and Lenox (2006); LiPuma (2006), Arping and Falconieri (2010)

Source: Authors' analysis 
Entrepreneurial ventures are a relevant source of innovation capability, and CVCs are dynamic and effective operators, highlighting the potential contributions of their $\mathrm{KM}$ strategies (Prieto et al., 2009; Sun, 2010) for IC building (Kianto et al., 2014).

Arping and Falconieri (2010) compared strategic and financial investors. Strategic objectives make it more valuable for an investor to produce high entrepreneurial effort, but they can undermine her/his commitment. Rather, investors often benefit from the success of the projects they finance not only for direct financial returns but also for synergies with their existing business lines, activating positive externalities on the corporation business.

The mere fact that the strategic investor internalizes the positive externality and appropriates the strategic benefit may allow him to break even at a lower rate of interest than an independent investor (p. 692).

and this lower financial break-even point seems to result in a direct though "invisible" effect of IC benefit accumulation on behalf of CVC (Liebowitz and Suen, 2000; Bontis and Fitzenz, 2002; Jamoussi et al., 2008: Krishnan and Ramasamy, 2011; Mohammad, 2016).

Fulghieri and Seviril (2009) analyzed the impact of competition on optimal organizations and financing structures of innovation-intensive industries, concluding that "[...] CVC, relative to IVC, leads to a greater probability that the start-up gets acquired by the established firm providing the CVC financing" (p. 1315). CVCs seem more desirable for early stage projects while IVCs appear to be more desirable for later stage projects.

Chemmanur et al. (2014) investigated how CVC differs from IVC in developing innovation in backed firms. "[...] CVCs appear to have a better ability to nurture innovation in their portfolio firms" (p. 2464), confirming CVC's propensity toward (even open) innovation management through KM processes (Natalicchio et al., 2017), establishing a virtuous circuit of backing, backed and other backed firms in the corporate portfolio not only exploring but also exploiting business creativity (Lee et al., 2018).

Alvarez-Garrido and Dushnitsky (2016) tested the innovation performance of CVC- and IVCbacked firms from patenting outcomes (Del Giudice et al., 2014): "[. . .] ventures' innovation output is sensitive to investor type: CVC-backed ventures are associated with greater publication and patenting output compared to peers backed solely by VCs" (p. 830). The performance of CVC-backed firms is sensitive to their capacities to benefit from corporate complementary assets, activating virtuous effects from knowledge exchange.

The exit strategies of CVC- and IVC-backed firms have been investigated in a number of studies. Guo et al. (2011) analyzed possible exit strategies for successful start-ups, sustaining that the contextual best exit route depends on multiple factors (venture profitability, the level of uncertainty, information asymmetry and the nature of the VC fund); the authors underscore that CVC-backed firms show lower discount rates than IVC-backed start-ups: this difference seems to be an effect of longer ventures, higher investment and higher rates of successful exits.

Finally, Hahn and Kang (2017) studied how syndicated investments of financial (IVC) and strategic (CVC) operators influence the performance of investee companies. "[...] IVCs and CVCs could face increasing conflicts when they syndicate their investment with a balanced distribution of ownership" (p. 77), providing indirect evidence of different approaches for IVCs (almost exclusively finance-oriented) and CVCs (also knowledge-oriented) in capital valuation.

\subsection{Institutional venture capitalists and corporate venture capitalist: comparison from a financial management perspective}

Numerous studies on IVC and CVC have explored technological innovation and value creation from the perspective of venture investors while little research has analyzed the financial impact of IVCs and CVCs: the "[...] literature on comparisons between IVC from 
standalone financial intermediaries and CVC is rather sparse" (LiPuma, 2006, p. 248). These studies, however, find major differences (cf. Table 2).

A preliminary difference between IVC and CVC concerns financial structures. Generally, IVC is organized as a limited liability partnership (LLP), raising funds to invest in start-ups, whereas CVC can assume various configurations from legal and organizational points of view: the CVC team is based in a business unit, and the parent corporation is the exclusive source of capital, providing support for Research \& Development (R\&D) and other functions of the backed firm.

Fund objectives are also different: IVCs are dedicated financial investors, whereas a CVC is a company with several lines of business and a strategic view of its investments: "As corporate subsidiaries, CVCs pursue both the strategic objectives of their parent companies and financial objectives, whereas IVCs' sole investment goal is to achieve high financial returns" (Chemmanur et al., 2014, p. 2435). Other scholars (Hellmann, 2002) have noted that while the sole aim of IVCs is a return on capital, a very important goal of most CVCs is the development of new related business, activating KM strategies and processes for IC accumulation (Kianto et al., 2014; Hussinki et al., 2017); CVCs do not aim to lose money, but their strategic focus is critical to their success (Cabrilo and Dahms, 2018).

Other important differences concern investment stages (cf. Figure 2): IVCs are capable of investing along the full funded business lifetime whereas CVCs are interested in specific phases. Fulghieri and Seviril (2009) sustained that corporate venturing is more desirable for early stage projects while institutional venturing is required in more phases of an entrepreneurial project, including later stages.

Gompers and Lerner (2000) sustained that CVCs invest slightly less in start-ups and mature private firms: the "[...] average life span of a CVC fund is far shorter than that of independent venture capital funds" (Dushnitsky and Lenox, 2006, p. 756). IVCs, compared to CVCs, are more interested in investing in a company over the long term.

CVCs are subject to constraints deriving from pressures to perform from a financial and strategic point of view. The duration of their investment cannot be determined in advance because of the need/opportunity to govern emerging environmental and entrepreneurial conditions, also from a KM point of view (Cegarra-Navarro et al., 2017). IVCs are generally structured as long-term commitments, where initial investments are made over the first three to five years: thereafter, a fund will operate follow-on investments over the rest of the financed firm lifecycle (CB Insights, 2016).

Concerning exit options, CVCs are open to several opportunities while IVCs prioritize high financial returns. CVCs have a wide range of outcomes that can derive from an investment, as financial returns are a fundamental benefit, but they are not the only opportunity, whereas IVCs only seek one form of performance, i.e. strong financial returns and targeting severe annual returns.

This implies, for example, that they will likely try to block the sale or initial public offering (IPO) of a backed firm until the price offers an adequate return (CB Insights, 2016) as a matter of how much and not why.

\section{Table 2 Financial comparison between IVC and CVC}

\begin{tabular}{lll} 
Profile & IVC & CVC \\
\hline Structure & Limited liability partnership (LLP) & $\begin{array}{l}\text { CVC is a business unit or headquarter } \\
\text { of a parent corporation } \\
\text { Strategic }\end{array}$ \\
Objective & Financial & From early to mid-stage \\
Stage & From idea to late stage & Not determined before \\
Duration & 10-years commitment usually & Do not seek tight control \\
Control level & Control over the portfolio & Different options (acquisition, partnership, other) \\
Exit (options) & Strong financial returns & \\
Source: Authors' analysis &
\end{tabular}




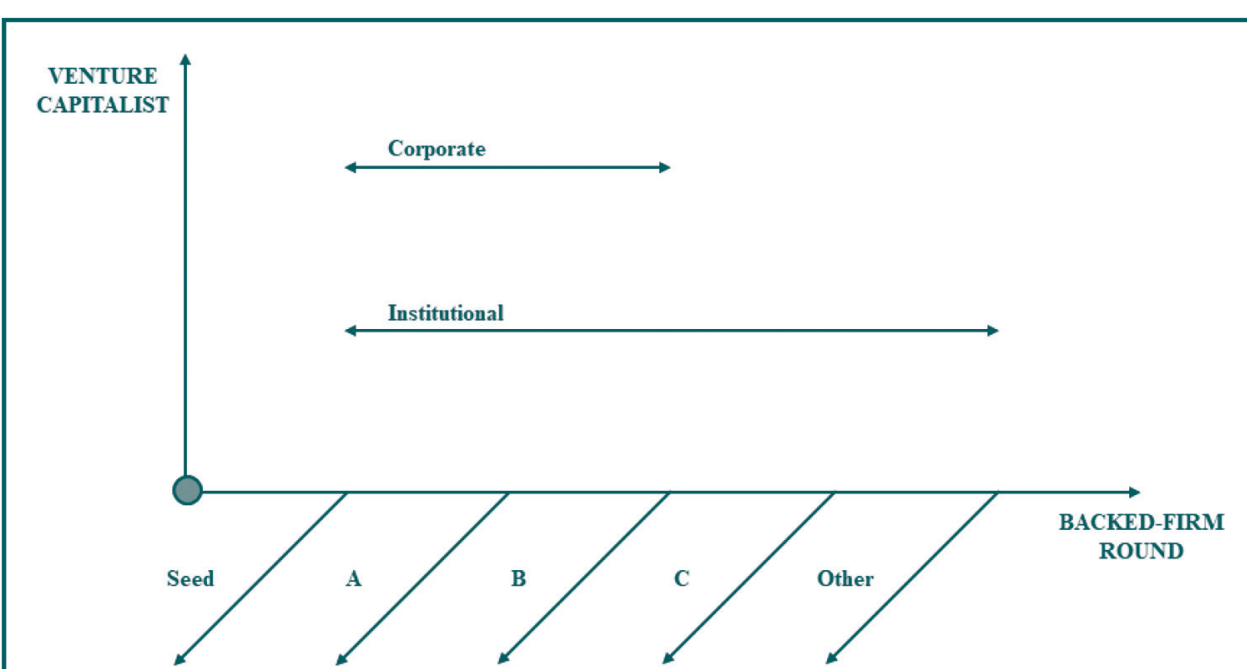

Source: Authors' elaboration

IVC funds are limited partnerships that pool and manage money from entities[. . . IVCs seek high financial returns by funding growth-oriented ventures[...] Through their CVC programs, established firms are also important players[...] Their objectives vary, though: some focus on achieving financial gain, while most CVC programs seek a window on novel technologies (Dushnitsky and Shapira, 2010, p. 993).

Another difference concerns levels of control: IVCs tend to control more of a company's decisions than CVCs, which prefer a board observer role rather than a seating role with a vote with less control over a company, though as an active partner (cf. Figure 3). CVCs prefer to "[...] avoid the board-related fiduciary responsibilities that would require them to act in a young firm's interest and preserve the flexibility to pursue their own strategic interests" (Hallen et al., 2014, p. 1081).

IVCs behave in the opposite manner: they want control over money invested into a firm and require a board seat for working strictly with a start-up's leadership team (Porporato, 2013; CB Insights, 2016). "IVCs may be more efficient in their resource allocation because they are structured as limited partnerships and have full control over the capital committed by their limited partners" (Chemmanur et al., 2014, p. 2436).

As a final difference, IVCs care more about quick exits than CVCs. IVC-backed start-ups have higher discount rates than those backed by CVCs. This discrepancy also affects human resource behaviors: IVC managers' compensation is more based on financial returns, and their ability to raise additional funds depends on their reputation, which is influenced by their past successes (Dushnitsky and Shapira, 2010), creating strong incentives to cash their returns from profitable projects early on (Guo et al., 2011). Compared to IVCs, CVCs managers have more available resources to use and to be evaluated on with direct reference to the parent corporation's knowledge base (Basu et al., 2011).

\subsection{Institutional venture capitalists and corporate venture capitalist ambidexterity from knowledge management behavior}

The concept of "organizational ambidexterity" is historically attributed to Duncan (1976), but March (1991) was probably the first scholar to conceive ambidexterity as a balance between exploitation and exploration. For firm survival, combining capacities to exploit 


\section{Figure 3 Control level and expected IVCs-CVCs funds}

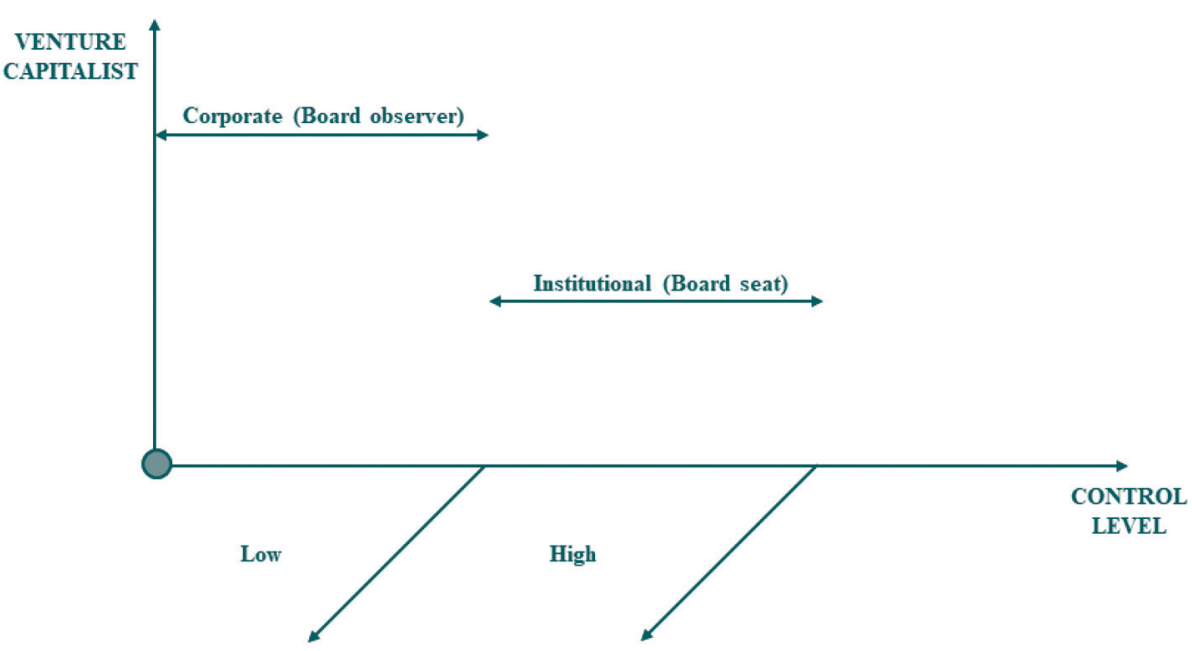

Source: Authors' elaboration

existing assets in a profit-producing way and to concurrently explore new knowledge, technologies and markets to capture existing and new opportunities is essential (March, 1991).

The relationship between ambidexterity and $\mathrm{KM}$ is evident: practices, routines, methods and processes concerning KM are sources of ambidexterity behaviors (Filippini et al., 2012; Del Giudice et al., 2018). This connection seems to be positively correlated - the broader the knowledge, the greater the degree of ambidexterity - giving importance to an organization's propensity toward knowledge accumulation (Lee and Huang, 2012).

Such an association seems to intensify when focusing on technology-related sectors, which are constantly exposed to development and evolution as observed in many situations concerning $\mathrm{VC}$, with continuous digital transformation affecting the physiological exigencies of such companies (Scuotto et al., 2019). Knowledge exchange and enhancing with ambidexterity orientation that could result from interactions between the investor and investee, as in the case of Mergers \& Acquisitions (Hughes et al., 2020), form the basis of a similar relationship that could emerge between IVCs and CVCs and their backed firms.

Although ambidexterity has become an emerging research trend for business organization and KM (Gibson and Birkinshaw, 2004), specific scientific literature on VC ambidexterity is still limited. Some scholars (Gibson and Birkinshaw, 2004; Rossi et al., 2019a) have recognized ambidexterity as one of the most important dynamic capabilities for VC, whereas Hill and Birkinshaw (2014) defined ambidexterity as "[. . .] the capacity to capitalize on an existing set of resources and capabilities while at the same time developing new combinations of resources to meet future market needs" (1899), Basu et al. (2011) argued that VC ambidexterity, specifically for corporate venturing, in addition to ensuring strategic flexibility, allows access to innovative resources, generating considerable competitiveness in mature and developed markets as well as in new sectors.

Gibson and Birkinshaw (2004) examined two main relationships: the first between ambidexterity and performance and the second between ambidexterity and organizational context. They found significant correlations, highlighting fundamental business contributions of two types of organizational ambidexterity, i.e. structural and contextual. They emphasized how contextual ambidexterity for CVCs ensures positive effects for their 
longevity, because the relationship between backed firms and CVC teams causes the investor, through appropriate knowledge sharing (Caniëls et al., 2017), to pursue exploration activities that exploit the resources of the entire corporation, returning an overall advantageous effect.

VC activity is physiologically oriented to find an appropriate equilibrium between exploration and exploitation (Rossi et al., 2019a). Achieving this balance likely involves the construction of a relational context (involving the ventured organization team and the VC community more generally) based on knowledge acquisition/creation/utilization and sharing (Sun, 2010; Cegarra-Navarro et al., 2018) with social (Prieto et al., 2009) and/or open modalities (Natalicchio et al., 2017), which can allow plain integration between firm-backed and corporate teams (Hill and Birkinshaw, 2014).

From the above considerations, KM system design and development seem essential for CVCs (Lee et al., 2015), which are continuously "thirsty" to accumulate knowledge through learning, acquiring and exploring, whereas, for IVCs, they could play a less relevant role in light of the more financial aims that IVCs should pursue, though IVCs cannot underestimate the benefits of expertise development (Agarwal et al., 2009). KM strategies and processes that can be enabled by VC operators and CVCs above all can be structural (establishing engaged approaches with every backed firm: Shaabani et al., 2012) or contextual (heavily depending on the specific business situation: Maula, 2007; Soto-Acosta et al., 2018), providing initial evidence and a consequent potential need for research drawing a possible analogy with organizational ambidexterity in general and VC-KM in particular.

\section{Research design}

From previous studies (mainly Hill and Birkinshaw, 2014; Rossi et al., 2019a; Rossi et al., 2019b), the investigation that follows shows preliminary findings on IVCs' and CVCs' activities to understand the potential ambidexterity of the main VCs around the world. To determine if they are ambidextrous or not, their differing natures (institutional and/or corporate) are considered to provide a global overview of their capacity for knowledge enhancing at internal and external levels (Mazzelli et al., 2019).

From a methodological point of view, the first phase of this research involved an overall analysis of the investment characteristics of the two types of operators, which was realized based on the number and size of operations, rounds of financing and sectorial/ geographical distributions. We conduct initial research focused on secondary data from a spatial and longitudinal point of view because of the complex nature of VC ambidexterity, especially when corporation-based (Basu et al., 2011); this is also why, as noted above, this topic has not been the object of much investigation so far.

The aim of the latter phase of this research was the construction of a conceptual context for categorizing institutional and corporate VCs as "ambidextrous," "hybrid" or "disambidextrous" (Rossi et al., 2019a), developing aggregate theorizations through observations of individual operators/operations. Considering this global design, the following research questions of a more quantitative nature were statistically investigated:

$R Q 1$. "Is there a positive correlation between the number of investments and their total amount per round for IVCs and CVCs?"

$R Q 2$. "Among investments operated by IVCs and CVCs, is entrepreneurial intensity stronger for IVCs or CVCs?"

Once statistical findings addressing these questions were obtained, two research questions of a more qualitative nature were investigated:

RQ3. "Are IVCs and CVCs ambidextrous organizations?"

$R Q 4$. "Are there any differences in ambidexterity among CVCs?" 
Thus, IVCs and CVCs have been classified in relation to ambidexterity based on three typologies of venture investors in relation to the level (high or low) of entrepreneurial intensity (EI) and the type (financial or strategic) of commitment. For Morris and Sexton (1996, p. 5), the:

[...] concept of entrepreneurial intensity (EI) is introduced to capture both the degree and amount of entrepreneurship evidenced within a given organization. It is hypothesized that levels of El are significantly associated with measures of company performance.

The three types of $\mathrm{VC}$ investors considered, each one expressing a different approach to knowledge enhancing, are the following (Rossi et al., 2019a):

1. Dis-ambidextrous, who are mainly interested in realizing high financial returns from investing in different companies with low levels of El and in focusing on the exploitation dimension.

2. Hybrid, who have not defined or programmed stable objectives with an average level of El (this situation can lead to the acquisition of new skills that can be useful for firm development, or it can be used as a strategy to select new investment opportunities).

3. Ambidextrous, who pursue strategic objectives through cooperation (this situation is characterized by high levels of El and a correct balancing of alignment with adaptability).

Finally, we adopt our final framework as a theoretical contribution to provide an overall overview of contemporary VC phenomena while focusing on two main topics of investigation. The first concerns the dynamics, results and specificities of IVC and CVC operations and operators by exploring the perspective of ambidexterity; the second concerns consequent implications for governing and managing IVCs' and CVCs' ambidexterity as a knowledge-enhancing capability.

\subsection{Data perimeters and codification}

The desk research conducted as the first part of this investigation is based on secondary data extracted from Crunchbase (www.crunchbase.com), one of the most relevant platforms for market information in the world. The study covers all IVC and CVC transactions made from January 1, 2019 to November 30, 2019 while omitting those without amount indications and using US $\$$ as the reference currency: data were first collected on the 15 most active US-based IVCs based on numbers of operations (cf. Table 3) and amounts (cf. Table 4).

Similar data were collected on the 15 most active US CVCs, which mainly operate in the technology sector and therefore in software, electronics, information technology (IT), artificial intelligence and telecommunications (cf. Tables 5 and 6).

From a quantitative point of view, the VC operators analyzed form a representative sample of the entire VC business: they account for $20.86 \%$ of global VC and $40.45 \%$ of the US VC when considering 2018 estimations (Toptal.com) and, respectively, 17.97\% (Crunchbase.com) and 37.85\% (Pitchbook.com) when considering 2019 estimations. From a qualitative point of view, investment rounds characterizing the transactions under investigation include the following.

- IVCs: Angel, Seed, Venture, Round A and Round B, Round C and following, Private equity, Debt financing, Secondary market, Grant, Corporate round, Post-IPO debt and Funding round.

- CVCs: Pre-seed, Seed, Venture, Round A and Round B, Round C and following, Corporate and Funding.

All data were organized into two separate databases (one for IVCs and the other for CVCs) using spreadsheet software. For convenience, all types of rounds are sorted under the following four categories. 
Table 3 Number of operations per stage from January to November 2019 (15 most active IVCs)

\begin{tabular}{lccrr} 
IVC & Round seed & Round A & Round B & Other \\
\hline Blackrock & 0 & 0 & 2 & 16 \\
Fidelity & 1 & 2 & 2 & 6 \\
Wellington Management & 0 & 0 & 2 & 6 \\
Franklin Templeton Investments & 0 & 2 & 3 & 9 \\
Goldman Sachs & 0 & 5 & 9 & 48 \\
T. Rowe Price & 0 & 0 & 2 & 15 \\
JP Morgan Chase & 0 & 1 & 2 & 13 \\
Morgan Stanley & 2 & 1 & 0 & 4 \\
Wells Fargo & 1 & 1 & 2 & 8 \\
Capital One & 1 & 0 & 0 & 3 \\
Kohlberg Kravis Roberts & 0 & 0 & 2 & 12 \\
SVB Financial Group & 0 & 1 & 1 & 3 \\
Social Capital & 4 & 2 & 1 & 1 \\
Prudential Financial & 0 & 0 & 1 & 3 \\
Starwood Capital Group & 1 & 0 & 0 & 2 \\
Total & 10 & 15 & 29 & 149 \\
Source: Authors' calculition
\end{tabular}

Source: Authors' calculation from www.crunchbase.com

Table 4 Invested amount per round from January to November 2019 (15 most active IVCs)

\begin{tabular}{|c|c|c|c|c|}
\hline IVC & Round seed & Round A & Round B & Other \\
\hline Blackrock & - & - & 230.00 & $7,337.13$ \\
\hline Fidelity & 1.90 & 33.00 & 64.00 & $1,088.00$ \\
\hline Wellington Management & - & - & 82.00 & 797.00 \\
\hline Franklin Templeton Investments & - & 19.90 & 71.00 & 828.36 \\
\hline Goldman Sachs & - & 64.00 & 657.90 & $6,493.05$ \\
\hline T. Rowe Price & - & - & 690.00 & $5,543.20$ \\
\hline JP Morgan Chase & - & 8.50 & 134.00 & $2,290.63$ \\
\hline Morgan Stanley & 0.63 & 35.00 & - & $2,367.30$ \\
\hline Wells Fargo & 2.25 & 1.50 & 73.30 & 159.03 \\
\hline Capital One & 8.00 & - & - & 710.00 \\
\hline Kohlberg Kravis Roberts & - & - & 240.00 & $8,004.59$ \\
\hline SVB Financial Group & - & 24.50 & 42.00 & 52.00 \\
\hline Social Capital & 8.23 & 38.50 & 49.50 & 140.00 \\
\hline Prudential Financial & - & - & 22.00 & 245.00 \\
\hline Starwood Capital Group & 5.00 & - & - & 54.50 \\
\hline Total & 26.01 & 224.90 & $2,355.70$ & $36,109.79$ \\
\hline
\end{tabular}

1. Seed: Seed and Pre-seed;

2. A: Round A;

3. B: Round B; and

4. Other: for IVCs, Angel, Venture, Round C and following, Private equity, Debt financing, Secondary market, Grant, Corporate round, Post-IPO debt and Funding round; for CVCs, Venture, Round C and following, Corporate and Funding.

\section{Findings analysis, interpretation and discussion}

\subsection{Results concerning venture capitalist co-evolution}

In exploring potential relationships between the number of transactions and corresponding invested amounts for each investment round, we first find that, in 2019, the IVCs under 


\begin{tabular}{|c|c|c|c|c|}
\hline CVC & Round seed & Round A & Round B & Other \\
\hline Google Ventures & 0 & 9 & 18 & 32 \\
\hline Intel Capital & 3 & 15 & 13 & 6 \\
\hline Comcast Ventures & 5 & 6 & 5 & 9 \\
\hline Salesforces Ventures & 2 & 12 & 12 & 28 \\
\hline Cisco Investments & 0 & 1 & 3 & 4 \\
\hline Johnson \& Johnson Innovation & 0 & 4 & 3 & 3 \\
\hline GE Ventures & 0 & 0 & 3 & 4 \\
\hline Qualcomm Ventures & 1 & 2 & 5 & 13 \\
\hline Bloomberg Beta & 10 & 4 & 2 & 3 \\
\hline Verizon Ventures & 0 & 2 & 0 & 1 \\
\hline Dell Technologies Capital & 0 & 7 & 6 & 4 \\
\hline M12 & 2 & 3 & 8 & 11 \\
\hline Amazon Alexa Fund & 7 & 1 & 1 & 1 \\
\hline Slack Fund & 5 & 9 & 3 & 0 \\
\hline Citi Ventures & 0 & 4 & 1 & 11 \\
\hline Total & 35 & 79 & 83 & 130 \\
\hline
\end{tabular}

Source: Authors' calculation from www.crunchbase.com

\begin{tabular}{llrrr} 
Table $6 \begin{array}{l}\text { Invested amount per round from January to November } 2019 \\
\text { CVCs) }\end{array}$ & \multicolumn{1}{c}{ Round $A$} & Round $B$ & Other \\
\hline CVC & Round seed & Roctive \\
\hline Google Ventures & - & 588.50 & $1,043.50$ & $3,196.50$ \\
Intel Capital & 11.70 & 199.90 & 479.50 & 377.00 \\
Comcast Ventures & 34.20 & 88.60 & 115.30 & 432.00 \\
Salesforces Ventures & 3.60 & 143.46 & 570.04 & $1,645.67$ \\
Cisco Investments & - & 8.00 & 69.00 & 166.00 \\
Johnson \& Johnson Innovation & - & 66.69 & 164.60 & 317.30 \\
GE Ventures & - & - & 44.40 & 184.60 \\
Qualcomm Ventures & 2.50 & 25.00 & 149.25 & 556.93 \\
Bloomberg Beta & 45.30 & 51.70 & 47.00 & 425.10 \\
Verizon Ventures & - & 33.00 & - & 30.00 \\
Dell Technologies Capital & - & 120.50 & 138.60 & 175.00 \\
M12 & 6.22 & 57.00 & 205.00 & 689.11 \\
Amazon Alexa Fund & 9.74 & 11.00 & 40.15 & 28.00 \\
Slack Fund & 21.20 & 282.30 & 50.00 & - \\
Citi Ventures & - & 49.52 & 20.00 & $1,047.84$ \\
Total & 134.46 & $1,725.17$ & $3,136.34$ & $9,271.05$
\end{tabular}

Source: Authors' calculation from www.crunchbase.com (million US\$)

analysis carried out 203 operations for a total value of approximately US $\$ 38 \mathrm{bn}$, and CVCs carried out 327 for a total value of approximately US\$14bn.

All operations are classified by sector and the geographic origin of the financed company. The following ten sectors are considered:

1. health care and biotechnology (HCB): biotechnology, health care and medical devices;

2. media and entertainment (MED): media, games and videos;

3. financial services (FIN): finance, credit, trading and insurance;

4. internet and related sectors (INT): the internet, wireless networks, Information and communication technology, IT security, networking and virtual reality; 
5. retail and distribution (RET): e-commerce and marketplaces;

6. mobile (MOB): mobile technologies and applications;

7. software (SOF): software and Big Data;

8. computer and related sectors (COM): computers, robotics, artificial intelligence, 3D technology and electronics;

9. industrial sectors (IND): automotive, semiconductors, energy and processing; and

10. remaining sectors (REM): various categories, including food, logistics, human resources, crowdfunding, education, universities, agriculture, real estate and others.

Concerning geographic areas, there is a clear prevalence of investments made in America (approximately $54 \%$ for IVCs and approximately $85 \%$ for CVCs), followed by those made in Asia (approximately 36\% for IVCs and approximately 9\% for CVCs) and Europe (approximately $9 \%$ for IVCs and approximately 6\% for CVCs). Low percentages are found for Oceania (approximately $1 \%$ for both operators) and almost nonexistent values are found for Africa (approximately $0.11 \%$ for IVCs).

The analysis of sectors shows that for IVCs, the most relevant is IND, representing approximately $31 \%$ of the total invested by the 15 operators under analysis, followed by REM (approximately 20\%), FIN (approximately 15\%) and INT (approximately 12\%). For CVCs, SOF slightly predominates, representing roughly $18 \%$ of the total invested by the 15 operators under analysis, followed by sectors with investment percentages of between 15\% and $11 \%$ (REM, INT, COM, HCB and FIN).

Regarding values related to the Rounds (cf. Figure 4), IVCs prefer "Other" investments at least in terms of the number of realized operations. CVCs too prefer "Other" investments, but not in the same way.

In analyzing the behaviors of single VC operators, data shown in Tables 3 and 4 demonstrate that IVCs carried out 10 operations in the Seed round (approximately US\$26m), 15 in Round A (approximately US\$225m), 29 in Round B (approximately US $\$ 2.4 \mathrm{bn}$ ) and 149 in the other types of rounds (approximately US\$36bn). Calculations show a strong positive correlation $(+0.997937)$ between the number of transactions and amounts invested per round.

On the other hand, data given in Tables 5 and 6 show that the CVCs carried out 35 operations in the Seed round (approximately US\$134m), 79 in Round A (approximately US $\$ 1.7 \mathrm{bn}$ ), 83 in Round B (approximately US\$3.1bn) and 130 in the other types of rounds (approximately US $\$ 9.3 \mathrm{bn})$. The correlation calculated between the number of transactions and amounts invested per round is highly positive (+0.945836).

These results show that both IVC and CVC operations present strong correlations between the number of transactions and amounts invested per round. The linear relationship between these variables shows a strong connection, and an affirmative answer to $R Q 1$ can thus be provided ("Is there a positive correlation between the number of investments and their total amount per round for IVCs and CVCs?" - "Yes").

While high, the two correlation coefficients show some differences $(+0.997937$ for IVCs and +0.945836 for CVCs) with a slight difference (0.052101). Evidence from the investigation shows that the IVCs under analysis have performed fewer operations than CVCs (203 for IVCs and 327 for CVCs), but IVCs invest almost triple the amount (US $\$ 38,716.04 \mathrm{~m}$ for IVCs and US $\$ 14,267.02 \mathrm{~m}$ for CVCs) with a tremendous difference of US\$24,449.02m; the average amount invested for IVCs operations is US $\$ 190.72 \mathrm{~m}$, whereas the average amount invested for CVCs operations is US $\$ 43.63 \mathrm{~m}$.

Using an approach used in similar research (Rossi et al., 2019a, 2019b), the entrepreneurial intensity of $\mathrm{VC}$ operations can be proxied by the product between the round weight and the invested amount: in this comparison, IVCs' and CVCs' same linear evolution through 


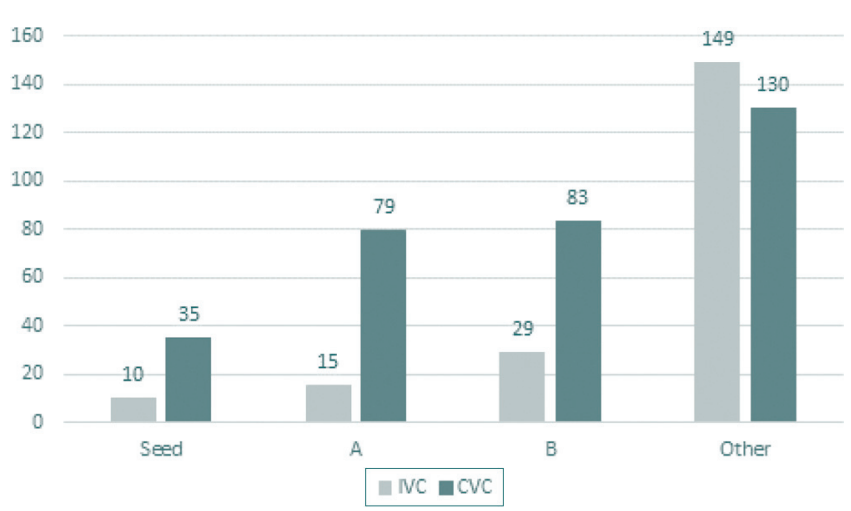

Source: Authors' calculation from www.crunchbase.com

different rounds can be "normalized" to the sole amount. From the above evidence, $R Q 2$ can be answered ("Among investments operated by IVCs and CVCs, is entrepreneurial intensity stronger for IVCs or CVCs?" - "IVCs").

\subsection{Results concerning venture capitalist ambidexterity}

Based on Rossi et al.'s (2019a) results and assuming organizational ambidexterity as an investigation criterion, VCs may operate as ambidextrous, hybrid or dis-ambidextrous. Such classifications are made using the following variables:

- financing round (FR);

- Entrepreneurial intensity (EI); and

- percentage of transactions carried out per round (OP).

Based on investment and transaction percentages for the various FRs, the ambidexterity classification for VCs is as follows:

- dis-ambidextrous: \% investing in the Seed round > \% investing in all other rounds;

- hybrid: \% investing in Round A or B > \% investing in all other rounds; and

- ambidextrous: \% investing in Round "Other" > \% investing in all other rounds.

El, the ambidexterity classification for VCs, for the data under investigation is measured as follows:

- dis-ambidextrous: El between US\$0 and US\$17.9m;

- hybrid: El between US\$18 and US\$30.9m; and

- ambidextrous: El higher than US\$31m.

A VC investor can be defined as ambidextrous with high levels of El and strategic interest, dis-ambidextrous with low levels of El and financial objectives or hybrid with moderate levels of El and mixed objectives (cf. Table 7). As noted above, El was calculated as the weighted sum of products between the round weight (Seed $=1$, Round $A=2$, Round $B=3$ and Other $=4$ ) and the invested amount per round from the percentage of operations carried out by type of round as a global weighting value.

For IVCs (cf. Table 8), all investors under investigation are classified as ambidextrous in relation to FR (confirming the aforementioned preference for high investment in the "Other" round) and El (as the average amount invested per transaction is equal to US\$190.72m). For OP, one IVC (social capital) emerges as dis-ambidextrous, as most transactions are carried out in the "Seed" round. 
- For FR, 13 CVCs can be classified as ambidextrous and 2 CVCs are classified as hybrid (Verizon Ventures and Slack Funds because of the greater amount of investments made in Round $A$ than in the other rounds).

- For El, all CVCs can be classified as ambidextrous (as the average amount invested per transaction is equal to US $\$ 43.63 \mathrm{~m})$.

- For OP, 11 CVCs are ambidextrous while 2 are hybrid (Verizon Ventures and Slack Funds because of the prevalence of operations executed in Round A) and 2 are disambidextrous (Bloomberg Beta and Amazon Alexa Funds because of the larger number of operations executed in the "Seed" round).

These results clearly show that the IVCs analyzed can be considered ambidextrous (only one is considered dis-ambidextrous and only in one case); instead, varied results emerge for CVCs. These differences are arguably the most important results of this research, providing a "segmented" response to RQ3: "Are IVCs and CVCs ambidextrous organizations?" - "Yes for IVCs and most of the times for CVCs."

These individual observations allow us to assume that ambidexterity is a physiological feature of IVCs. This evidence can reflect both confirmation and doubt: for confirmation, IVCs are naturally ambidextrous, as they try to maximize the efficiency of their (prevailingly financial) resources by continuously investing in new opportunities (also and mostly outside of their strategic perimeters); for doubts, by contrast, CVCs should, in practice, be even more ambidextrous than

\begin{tabular}{|c|c|c|c|}
\hline $\begin{array}{l}\text { IVC } \\
\text { CVC }\end{array}$ & $\begin{array}{l}\text { Financing round } \\
\text { (amount in \%) }\end{array}$ & $\begin{array}{l}\text { Entrepreneurial intensity } \\
\text { (million US\$) }\end{array}$ & $\begin{array}{l}\text { Operations } \\
\text { (\% per rounds) }\end{array}$ \\
\hline Dis-ambidextrous & Prominence in Round "Seed" & $00.00<\mathrm{EI}<17.90$ & $\begin{array}{l}\text { Prominence in Round } \\
\text { "Seed" }\end{array}$ \\
\hline Hybrid & Prominence in Round A and B & $18.00<\mathrm{EI}<30,90$ & $\begin{array}{l}\text { Prominence in Round } \\
A \text { and } B\end{array}$ \\
\hline Ambidextrous & Prominence in Round "Other" & $31,00<\mathrm{El}$ & $\begin{array}{l}\text { Prominence in Round } \\
\text { "Other" }\end{array}$ \\
\hline
\end{tabular}

\section{Table 8 Classification of the IVCs under investigation on an ambidexterity basis}

\begin{tabular}{llll} 
IVC & FR & El & OP \\
\hline Blackrock & Ambidextrous & Ambidextrous & Ambidextrous \\
Fidelity & Ambidextrous & Ambidextrous & Ambidextrous \\
Wellington Management & Ambidextrous & Ambidextrous & Ambidextrous \\
Franklin Templeton Inv. & Ambidextrous & Ambidextrous & Ambidextrous \\
Goldman Sachs & Ambidextrous & Ambidextrous & Ambidextrous \\
T. Rowe Price & Ambidextrous & Ambidextrous & Ambidextrous \\
JP Morgan Chase & Ambidextrous & Ambidextrous & Ambidextrous \\
Morgan Stanley & Ambidextrous & Ambidextrous & Ambidextrous \\
Wells Fargo & Ambidextrous & Ambidextrous & Ambidextrous \\
Capital One & Ambidextrous & Ambidextrous & Ambidextrous \\
Kohlberg Kravis Roberts & Ambidextrous & Ambidextrous & Ambidextrous \\
SVB Financial Group & Ambidextrous & Ambidextrous & Ambidextrous \\
Social Capital & Ambidextrous & Ambidextrous & Dis-ambidextrous \\
Prudential Financial & Ambidextrous & Ambidextrous & Ambidextrous \\
Starwood Capital Group & Ambidextrous & Ambidextrous & Ambidextrous \\
Source: Authors' calculation & & &
\end{tabular}


Table 9 Classification of the CVCs under investigation on an ambidexterity basis

\begin{tabular}{llll} 
CVC & FR & El & OP \\
\hline Google Ventures & Ambidextrous & Ambidextrous & Ambidextrous \\
Intel Capital & Ambidextrous & Ambidextrous & Ambidextrous \\
Comcast Ventures & Ambidextrous & Ambidextrous & Ambidextrous \\
Salesforce Ventures & Ambidextrous & Ambidextrous & Ambidextrous \\
Cisco Investments & Ambidextrous & Ambidextrous & Ambidextrous \\
Johnson \& Johnson Innovation & Ambidextrous & Ambidextrous & Ambidextrous \\
GE Ventures & Ambidextrous & Ambidextrous & Ambidextrous \\
Qualcomm Ventures & Ambidextrous & Ambidextrous & Ambidextrous \\
Bloomberg Beta & Ambidextrous & Ambidextrous & Dis-ambidextrous \\
Verizon Ventures & Hybrid & Ambidextrous & Hybrid \\
Dell Technologies Capital & Ambidextrous & Ambidextrous & Ambidextrous \\
M12 & Ambidextrous & Ambidextrous & Ambidextrous \\
Amazon Alexa Fund & Ambidextrous & Ambidextrous & Dis-ambidextrous \\
Slack Fund & Hybrid & Ambidextrous & Hybrid \\
Citi Ventures & Ambidextrous & Ambidextrous & Ambidextrous \\
Source: Authors' calculation & & &
\end{tabular}

IVCs, as CVCs try to maximize the efficiency of their (global) resources by continuously investing in new opportunities (but also and mostly within their organizational perimeters).

\subsection{Results emerging from discriminant analyses of corporate venture capitalists}

The above investigation of VC data reveals "more" potential ambidexterity for IVCs than for CVCs, although our literature review seems to show different results; nonetheless, this empirical study also shows that most CVCs are ambidextrous. As our assessment of CVC ambidexterity shows some heterogeneity, a discriminant analysis was conducted on this type of investor to address RQ4 ("Are there any differences in ambidexterity among CVCs?").

The above calculations on VC ambidexterity show controversial evidence on the classification of CVCs as dis-ambidextrous, hybrid or ambidextrous when assuming OP as a parameter (cf. Table 9). This criterion generates the most differences (4/15, while FR 2/15, and $\mathrm{EI} \mathrm{O/15),} \mathrm{and} \mathrm{thus} \mathrm{this} \mathrm{factor} \mathrm{was} \mathrm{investigated} \mathrm{in} \mathrm{a} \mathrm{subsequent} \mathrm{discriminant} \mathrm{analysis.}$

The technique used allowed us to study matrixes from a privileged parameter, i.e. the variable under investigation, through the lens of other explanatory variables. In the following analysis, which was conducted using common statistical software, the potential discriminating role of the OP criterion in CVC ambidexterity is investigated using the following 16 variables (cf. previous cataloguing):

1. total number of operations (OPN);

2. investment \% in America (AME);

3. investment \% in Europe (EUR);

4. investment \% in Asia (ASI);

5. investment \% in Oceania (OCE);

6. investment \% in Africa (AFR);

7. investment \% in $\mathrm{HCB}$;

8. investment \% in MED;

9. investment \% in FIN;

10. investment \% in INT;

11. investment \% in RET; 
12. investment \% in MOB;

13. investment \% in SOF;

14. investment \% in $\mathrm{COM}$;

15. investment \% in IND; and

16. investment \% in REM;

The results of the analysis, as shown by the contingency prospect (cf. Table 10), confirm the starting classification (2 dis-ambidextrous, 2 hybrid and 11 ambidextrous) in relation to OP as a discriminant variable for classifying CVC ambidexterity. These divergences are likely consequences of the different kinds of knowledge - financial or organizational - strategically activated: ambidextrous organizations mainly invest with strategic interest in later stages, which are normally less risky considering venture-backed firms' prolonged presence in market; by contrast, dis-ambidextrous organizations preferably operate in early stages, mainly investing in various businesses to achieve their financial goals; and finally, hybrid organizations mostly focus on early stages (mostly Round A) such as dis-ambidextrous organizations but with mixed interests.

The following examinations aim to determine if a sectorial/geographic subcriterion could have exercised some influence on CVC ambidexterity. The 16 variables listed above are used for further subclassification (cf. Tables 11 and 12), from which an in-depth analysis provides clearer results.

When investigating the OP criterion in more depth, more controversial considerations arise: a comparison of Tables 11 and 12 shows an increase in dis-ambidextrous (from 2 to 4 ) and hybrid CVCs (from 2 to 3 ) and a decrease in ambidextrous CVCs (from 11 to 8). Further investigations may highlight also other even major differences, showing that the OP criterion, while fairly important, may not be appropriate for ambidexterity classification because of several contextual effects-related divergences in opportune KM strategies (Del Giudice et al., 2012).

\section{A theoretical model for venture capitalist ambidexterity adopting a knowledge management perspective}

From the abovementioned considerations and placing business knowledge stock at the center of analysis (Wu and Shanley, 2009), a qualitative framework was conceived, developed and analyzed. The resulting model is based on the following three binomial dimensions assuming a VC (institutional or corporate) perspective:

- knowledge to accumulate (KTA): financial (normally, but not exclusively, IVCs) or more strategic (normally, but not exclusively, CVCs);

- knowledge to exploit (KTET): financial (normally, but not exclusively, IVCs) or strategic (normally, but not exclusively, CVCs); and

- knowledge to explore (KTEE): financial (normally, but not exclusively, IVCs) or strategic (normally, but not exclusively, CVCs).

The graph shown in Figure 5 is engineered as follows:

\section{Table 10 Contingency table}

\section{CVC}

Dis-ambidextrous

Hybrid

Ambidextrous
Dis-ambidextrous

2

0
Hybrid

Ambidextrous

Source: Authors' calculation 
Table 11 Variables group averages

\begin{tabular}{|c|c|c|c|c|c|c|c|c|c|c|c|c|c|c|c|c|}
\hline NATURE & OPN & $A M E$ & EUR & $A S I$ & $O C E$ & AFR & $H C B$ & MED & FIN & INT & RET & $M O B$ & SOF & COM & IND & REM \\
\hline Dis-ambidextrous & 12.50 & 00.98 & 00.02 & 00.00 & 00.00 & - & 00.00 & 00.08 & 00.01 & 00.01 & 00.00 & 00.25 & 00.10 & 00.19 & 00.00 & 00.37 \\
\hline Hybrid & 10.00 & 01.00 & 00.00 & 00.00 & 00.00 & - & 00.00 & 00.00 & 00.04 & 00.51 & 00.00 & 00.00 & 00.44 & 00.01 & 00.00 & 00.00 \\
\hline Ambidextrous & 25.27 & 00.82 & 00.04 & 00.13 & 00.01 & - & 00.13 & 00.01 & 00.08 & 00.18 & 00.06 & 00.05 & 00.21 & 00.14 & 00.10 & 00.05 \\
\hline
\end{tabular}

Table 12 Prevailing CVC behavior with respect to single variable of study

\begin{tabular}{|c|c|c|c|c|c|c|c|c|c|c|c|c|c|c|c|c|}
\hline NATURE & OPN & AME & EUR & ASI & OCE & $A F R$ & $H C B$ & MED & FIN & INT & $R E T$ & $M O B$ & SOF & COM & IND & REM \\
\hline Dis-ambidextrous & & & & & & - & & $x$ & & & & $x$ & & $x$ & & $x$ \\
\hline Hybrid & & $x$ & & & & - & & & & $x$ & & & $x$ & & & \\
\hline Ambidextrous & $x$ & & $x$ & $x$ & $x$ & - & $x$ & & $x$ & & $x$ & & & & $x$ & \\
\hline
\end{tabular}

- The X-axis shows "knowledge to accumulate" for the VC ("financial" or "strategic").

- The Y-axis shows "knowledge to exploit" for the VC ("financial" or "strategic").

- The Z-axis shows "knowledge to explore" for the VC ("financial" or "strategic").

This theoretical framework relies on eight conceptual positions, which can be paired with their own most adequate VC behaviors in terms of ambidexterity:

- 1: (financial KTA, financial KTET, strategic KTEE): both (more IVC than CVC);

- 2: (strategic KTA, financial KTET, strategic KTEE): both (more CVC than IVC);

- 3:(strategic KTA, financial KTET, financial KTEE): both (more IVC than CVC);

- 4: (financial KTA, financial KTET, financial KTEE): IVC;

- 5: (financial KTA, strategic KTET, strategic KTEE):both (more CVC than IVC);

- 6: (strategic KTA, strategic KTET, strategic KTEE):CVC;

- 7: (strategic KTA, strategic KTET, financial KTEE):both (more CVC than IVC); and

- 8: (financial KTA, strategic KTET, financial KTEE):both (more IVC than CVC).

Ambidexterity seems more typical of VC investments with strategic KTEE at least with respect to the core business of the backing company, and it can be exerted by IVCs and CVCs as well. Further combinations involving KTA and KTET may lead to other suggestions, confirming through this qualitative interpretation results emerging from the literature review, providing more evidence of ambidexterity as a potential outcome of major KM adoption and IC accumulation for CVCs rather than for IVCs.

The model is designed to support a strategic analysis of VC approaches with methodological representations having knowledge (to accumulate/exploit/explore) as a crucial pillar. Naturally, it cannot represent every single form of VC ambidexterity that can occur, but compared to the previous investigation of the 15 most active IVCs and CVCs in the world, it seems capable of providing a systematic global overview of VC ambidexterity when analyzed through the abovementioned binomial dimensions.

\section{Research limitations and avenues for future research}

The most relevant issue concerning the reliability of this study relates to the sample used. The number of organizations under examination (the 15 most active IVCs and CVCs in the 
Figure 5 Theoretical framework for VC ambidexterity from a KM perspective

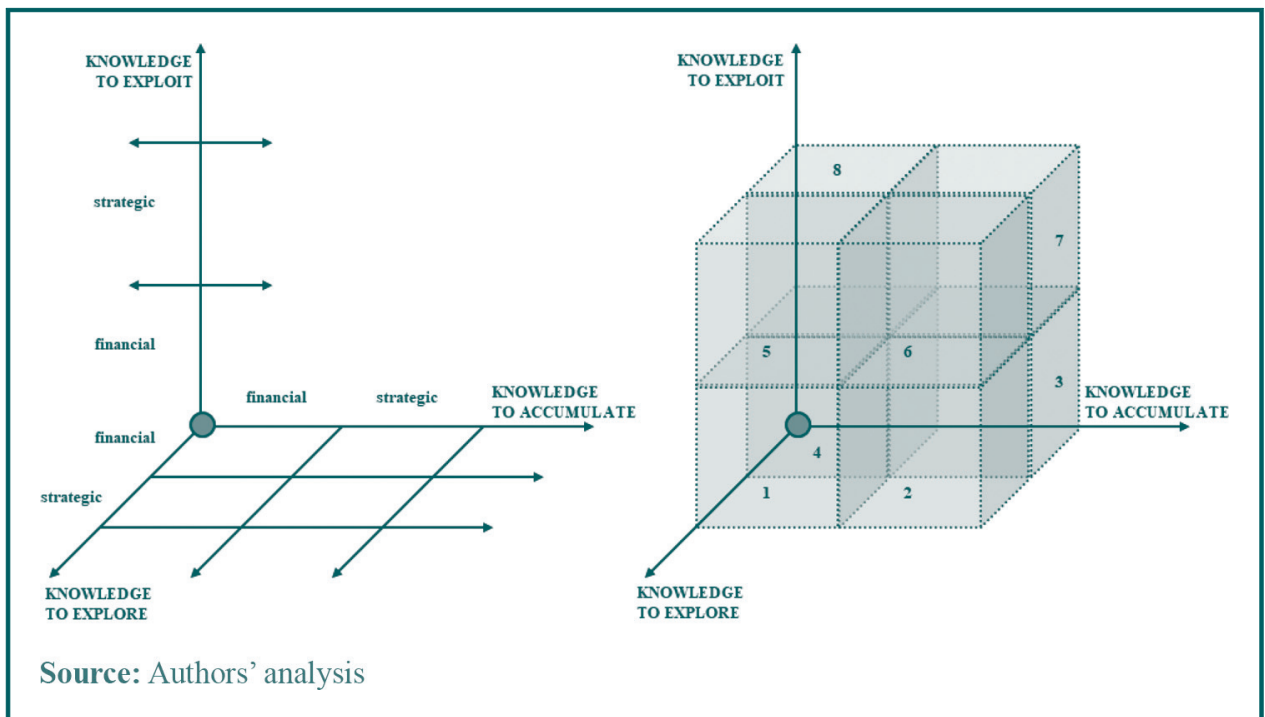

world) is not statistically representative of the examined categories, though their "substantial" representativeness should be evident. Future research examining larger samples of VCs could lend further robustness to global analysis.

Another limitation concerns our investigation period: because of obvious exigencies concerning the volume of possible calculations, only the year 2019 is considered. Given the controversial results obtained when using the OP classification criterion to study CVCs ambidexterity, expanding the time period under examination could allow for a better understanding of the phenomenon, confirming or even disconfirming the bias found for this parameter.

From a methodological point of view, the present research was conducted at the individual (the 15 most active IVCs and CVCs) and categorical levels (IVCs or CVCs only) adopting an abductive approach (Del Giudice et al., 2017b): from evidence emerging from the investigation (IVCs are physiologically ambidextrous whereas CVCs are not always), subsequent reasoning is part of a consequential induction (then an abduction) of a global behavior model on VC ambidexterity. Drawing more observations could for more cases help verify (or discount) the validity of the so-constructed theoretical framework.

Moreover, the knowledge dynamics analyzed were investigated using a speculative model focusing on only two forms, financial and strategic, to reduce the potential hypercomplexities of the theoretical framework. To enhance the results of other studies (Vrontis et al., 2017), future research could generate further findings by focusing first on more specific types of knowledge (not limited to a generic "strategic" dimension, but specifically concerning R\&D, technology, marketing and so on) and second on their possible combinations by developing from an strategic business unit approach (Abell, 1980) a sort of business knowledge unit approach (Bolisani and Bratianu, 2017; Santoro et al., 2019; Scuotto et al., 2020).

\section{Conclusion}

Scientific studies on IVCs and CVCs have been growing far and wide; however, analyses on their similarities and differences merit further discussion. Moreover, the fragmentation of literature of this field has sometimes prevented the formulation of a general theory on this topic. 
The current lack of consensus in this respect underscores its complexity: the literature review presented in the current work shows that there is no single, unified point of view on relationships between IVCs and CVCs. Nonetheless, our investigation of the 15 most active IVCs and CVCs highlights that while we provide a progressive understanding of the phenomenon, there are still many issues to debate regarding their different dynamics, particularly regarding their $\mathrm{KM}$ for potential ambidexterity.

The findings of this research highlight that IVCs and CVCs show positive correlations between the number of operations and their amounts, whereas IVCs show higher degrees of entrepreneurial intensity. Moreover, IVCs seem to be naturally ambidextrous, whereas this is the case for only the majority of CVCs, though with relevant differences.

CVCs attend to only a part of venture-backed firms' lives, impacting their selection effects on launching or developing start-ups. Despite CVCs having not tight control over financed companies, their investment, at least relative to IVCs, tends to increase firms' value of invested ventures and consequently that of venturing corporations (further explaining why, in the current investigation, some CVC operations were classified as ambidextrous when considering their OP).

CVC funds operate with lower financial resources but with more involvement in other strategic resources (organization, R\&D, logistics and so forth), highlighting major interest in overall business knowledge enhancement (Santoro et al., 2019). The tendency for CVCs to invest in sectors related to their core business finds justification in their strategic goals while IVCs tend to diversify their operations to reduce overall risks of their investment portfolios (from an ambidextrous point of view, exploring not for exploring, but for exploiting).

The current research has also shown complementarity between these investors, confirming Arping and Falconieri's (2010) statement that: "[...] corporate and independent venture capital are actually complements, rather than substitutes" (p. 708). IVCs and CVCs can have diverse but strongly complementary value-added profiles, which are differently useful to venture-backed firms (Maula et al., 2005), and from a KM perspective, this reasoning has been compacted into the developed theoretical framework on IVC and CVC ambidexterity.

\section{Scientific and managerial implications}

From a theoretical point of view, our research findings allow for the development of a behavior model on ambidexterity for IVCs and CVCs, enhancing through a logical framework the evidence that has emerged from their comparative analysis. This scientific result appears very impactful, empirically providing IVCs the natural essence of ambidextrous companies, whereas CVCs seem to not always be ambidextrous; however, other related considerations could be different, and this contradiction could be misleading if not correctly contextualized.

From our literature review, ambidextrous behaviors seem to be more appropriate for CVCs than for IVCs: IVCs are expected to be more explorative (searching for new investment opportunities with financial goals) whereas CVCs are expected to be both explorative and exploitative (with financial but mostly strategic goals). Specifically, CVC ambidexterity should be a result of more diffused KM adoption and IC accumulation than for IVCs.

The empirical results of the current investigation show that CVCs can adopt different behaviors in terms of ambidexterity: a focus on their operations shows that the most influential criterion for this illusory contradiction (i.e. the OP criterion) serves as a continuous source for even major differences. The logical interpretation seems clear: CVCs are oriented toward acting ambidextrously to enhance business knowledge, and this sensitivity allows (or forces) them to use different strategies (sometimes completely ambidextrous or not) in the midst of different conditions.

These various approaches to business knowledge valorization also impact the detection of the strategic paradigm that should be at the basis of different VC behaviors. According to our empirical analysis and the theoretical reconstruction implemented, IVCs seem 
ambidextrous from a resource-based view given the financial nature of their operations, whereas CVCs seem to be more ambidextrous from a knowledge-based view with relevant consequences for systems governing and managing their assets.

The practical implications of our results are even more significant. Entrepreneurs and managers of IVCs can assume that their companies should work physiologically as ambidextrous, providing the global organization with useful resources and their efficient combination in terms of both material (financial) and intellectual assets (e.g. human capital) (Bontis and Fitzenz, 2002). At the same time, entrepreneurs and managers of CVCs can assume that their companies, while "logically" more oriented toward ambidexterity, cannot be strictly ambidextrous because of their continuous tensions with knowledge enhancement, as CVCs can, for single operations, decide to be not ambidextrous (acting as dis-ambidextrous or hybrid); even more in these cases, KM strategies and intellectual more than material capital accumulation (at the human, structural, and relational levels) are indispensable.

crunchbase.com

pitchbook.com

toptal.com

\section{References}

Abell, D.F. (1980), Defining the Business: The Starting Point of Strategic Planning, Prentice-Hall, Englewood Cliffs, NJ.

Agarwal, A., Agarwal, S. and Solojentsev, E.D. (2009), "Venture finance model for HR capacity building in global dis-equilibrium", Keynote Address at Russian Academy of Science MASR, 7-11 July 2009, Saint Petersburg, Russia, pp. 1-27.

Alvarez-Garrido, E. and Dushnitsky, G. (2016), “Are entrepreneurial venture's innovation rates sensitive to investor complementary assets? Comparing biotech ventures backed by corporate and independent VCs", Strategic Management Journal, Vol. 37 No. 5, pp. 819-834.

Arping, S. and Falconieri, S. (2010), "Strategic versus financial investors: the role of strategic objectives in financial contracting", Oxford Economic Papers, Vol. 62 No. 4, pp. 691-714.

Basu, S., Phelps, C. and Kotha, S. (2011), "Towards understanding who makes corporate venture Capital investments and why", Journal of Business Venturing, Vol. 26 No. 2, pp. 153-171.

Blomkvist, M., Johansson, J. and Malmström, M. (2016), "Accounting knowledge in innovative firms direct contacts with external auditors for strategic actions", International Journal of Managerial and Financial Accounting, Vol. 8 Nos 3/4, pp. 209-229.

Bolisani, E. and Bratianu, C. (2017), "Knowledge strategy planning: an integrated approach to manage uncertainty, turbulence, and dynamics", Journal of Knowledge Management, Vol. 21 No. 2, pp. 233-253.

Bontis, N. and Fitzenz, J. (2002), "Intellectual Capital ROI: a causal map of human Capital antecedents and consequents", Journal of Intellectual Capital, Vol. 3 No. 3, pp. 223-247.

Boston Consulting Group (2018), "How the best corporate venturers keep getting better", available at: http://image-src.bcg.com/Images/BCG-How-the-Best-Corporate-Venturers-Keep-Getting-Better-Aug-2018_ tcm9-200601.pdf (access 20 March 2020).

Cabrilo, S. and Dahms, S. (2018), "How strategic knowledge management drives intellectual Capital to superior innovation and market performance", Journal of Knowledge Management, Vol. 22 No. 3, pp. 621-648.

Caniëls, M., Neghina, C. and Schaetsaert, N. (2017), "Ambidexterity of employees: the role of empowerment and knowledge sharing", Journal of Knowledge Management, Vol. 21 No. 5, pp. 1098-1119.

CB Insights (2016), "Corporate VC vs VC: corporate venture capital's priorities differ from institutional VCs", available at: www.cbinsights.com/research/corporate-venture-capital-institutional-venture-capital/ (access 20 March 2020).

Cegarra-Navarro, J.G., Jiménez-Jiménez, D., García-Pérez, A. and Del Giudice, M. (2018), "Building affective commitment in a financial institution through an ambidexterity context", European Business Review., Vol. 30 No. 1. 
Cegarra-Navarro, J., Wensley, A., Jimenez-Jimenez, D. and Sotos-Villarejo, A. (2017), "Linking procedural memory with organizational learning through knowledge corridors", Journal of Knowledge Management, Vol. 21 No. 6, pp. 1503-1522.

Chemmanur, T.J., Loutskina, E. and Tian, X. (2014), "Corporate venture Capital, value creation, and innovation", Review of Financial Studies, Vol. 27 No. 8, pp. 2434-2473.

Dagogo, D. and Ollor, W. (2009), "The effect of venture Capital financing on the economic value added profile on Nigerian SMEs", African Journal of Accounting, Economics, Finance and Banking Research, Vol. 5 No. 5, pp. 37-46.

Del Giudice, M., Carayannis, E.G. and Della Peruta, M.R. (2012), "Culture and cooperative strategies: knowledge management perspectives", pp. 49-62. In Del Giudice, M., Carayannis, E.G. and Della Peruta, M.R. (Eds.), Cross-Cultural Knowledge Management, Springer, New York, NY.

Del Giudice, M., Carayannis, E.G. and Maggioni, V. (2017a), "Global knowledge intensive enterprises and international technology transfer: emerging perspectives from a quadruple helix environment", The Journal of Technology Transfer, Vol. 42 No. 2, pp. 229-235.

Del Giudice, M., Maggioni, V., Romano, M. and Nicotra, M. (2014), "Knowledge creation and exploitation in italian universities: the role of internal policies for patent activity", Journal of Knowledge Management, Vol. 18 No. 5, pp. 952-970.

Del Giudice, M., Soto-Acosta, P., Carayannis, E. and Scuotto, V. (2018), "Emerging perspectives on business process management (BPM): IT-based processes and ambidextrous organizations, theory and practice", Business Process Management Journal, Vol. 24 No. 5, pp. 1070-1076.

Del Giudice, M., Khan, Z., De Silva, M., Scuotto, V., Caputo, F. and Carayannis, E. (2017b), "The microlevel actions undertaken by owner-managers in improving the sustainability practices of cultural and creative small and medium enterprises: a United Kingdom-Italy comparison", Journal of Organizational Behavior, Vol. 38 No. 9, pp. 1396-1414.

Denford, J. (2013), "Building knowledge: developing a knowledge-based dynamic capabilities typology", Journal of Knowledge Management, Vol. 17 No. 2, pp. 175-194.

Duncan, R. (1976), "The ambidextrous organization: designing dual structures for innovation", in Killman, R.H., Pondy, L.R. and Sleven, D. (Eds), The Management of Organization, North Holland, New York, NY, pp. 167-188.

Dushnitsky, G. (2012), “Corporate venture Capital in the twenty-first century: an integral part of firms' innovation toolkit", in Cumming D. (Ed.), The Oxford Handbook of Venture Capital, Oxford University Press, New York, NY, pp. 156-210.

Dushnitsky, G. and Lenox, M.J. (2006), "When does corporate venture Capital investment create firm value?", Journal of Business Venturing, Vol. 21 No. 6, pp. 753-772.

Dushnitsky, G. and Shapira, Z. (2010), "Entrepreneurial finance meets organizational reality: comparing investment practices and performance of corporate and independent venture capitalists", Strategic Management Journal, Vol. 31 No. 9, pp. 990-1017.

Filippini, R., Güttel, W.H. and Nosella, A. (2012), "Ambidexterity and the evolution of knowledge management initiatives”, Journal of Business Research, Vol. 65 No. 3, pp. 317-324.

Fulghieri, P. and Seviril, M. (2009), "Organization and financing of innovation, and the choice between corporate and independent venture Capital", Journal of Financial and Quantitative Analysis, Vol. 44 No. 6, pp. $1291-1321$.

Gibson, C.B. and Birkinshaw, J. (2004), "The antecedents, consequences, and mediating role of organizational ambidexterity”, Academy of Management Journal, Vol. 47 No. 2, pp. 209-226.

Gompers, P.A. and Lerner, J. (2000), "The determinants of corporate venture Capital success organizational structure, incentives, and complementarities", in Mork, R.K. (Ed.), Concentrated Corporate Ownership, University of Chicago Press, Chicago, IL, pp. 17-54.

Gompers, P.A. and Lerner, J. (2001), The Money of Invention: How Venture Capital Creates New Wealth, Harvard Business School Press, Boston, MA.

Guo, B., Lou, Y. and Pérez-Castillo, D. (2011), "Optimal exit strategy for CVC and IVC backed startups", Working Paper, available at: https://editorialexpress.com/cgi-bin/conference/download.cgi?db_name= ASSET2011\&paper_id=162 (access 20 March 2020). 
Hahn, S. and Kang, J. (2017), "Complementary or conflictory?: the effects of the composition of the syndicate on venture Capital-backed IPOs in the US stock market", Economia e Politica Industriale, Vol. 44 No. 1, pp. 77-102.

Hallen, B.L., Katila, R. and Rosenberger, J.D. (2014), "How do social defenses work? a ResourceDependence lens on technology ventures, venture Capital investors, and corporate relationships", Academy of Management Journal, Vol. 57 No. 4, pp. 1078-1101.

Hellmann, T. (2002), "A theory of strategic venture investing", Journal of Financial Economics, Vol. 64 No. 2, pp. 285-314.

Hill, S.A. and Birkinshaw, J. (2014), "Ambidexterity and survival in corporate venture units", Journal of Management, Vol. 40 No. 7, pp. 1899-1931.

Hisrich, R.D. and Peters, M.P. (1998), Entrepreneurship: Starting, Developing and Managing a New Enterprise, Irwin, Chicago, IL.

Hughes, P., Hughes, M., Stokes, P., Lee, H., Rodgers, P. and Degbey, W.Y. (2020), "Micro-foundations of organizational ambidexterity in the context of cross-border mergers and acquisitions", Technological Forecasting and Social Change, Vol. 153 No. 2020, pp. 1-14, doi: 10.1016/j.techfore.2020.119932.

Hussinki, H., Ritala, P., Vanhala, M. and Kianto, A. (2017), "Intellectual Capital, knowledge management practices and firm performance", Journal of Intellectual Capital, Vol. 18 No. 4, pp. 904-922.

Jamoussi, W., Baklouti, M.A. and Affes, H. (2008), "Relevance of intangible in the evaluation of firms: case of the French market", International Journal of Managerial and Financial Accounting, Vol. 1 No. 1 , pp. 115-125.

Kianto, A., Ritala, P., Spender, J. and Vanhala, M. (2014), "The interaction of intellectual Capital assets and knowledge management practices in organizational value creation", Journal of Intellectual Capital, Vol. 15 No. 3, pp. 362-375.

Krishnan, A. and Ramasamy, R. (2011), "The key financial and non-financial performance measures of manufacturing firms in Malaysia", International Journal of Managerial and Financial Accounting, Vol. 3 No. 4, pp. 403-417.

Lee, C. and Huang, Y. (2012), "Knowledge stock, ambidextrous learning, and firm performance", Management Decision, Vol. 50 No. 6, pp. 1096-1116.

Lee, S., Kim, T. and Jang, S. (2015), "Inter-organizational knowledge transfer through corporate venture Capital investment", Management Decision, Vol. 53 No. 7, pp. 1601-1618.

Lee, S.U., Park, G. and Kang, J. (2018), "The double-edged effects of the corporate venture Capital unit's structural autonomy on corporate investors' explorative and exploitative innovation”, Journal of Business Research, Vol. 88 No. 2018, pp. 141-149.

Lerner, J. (2009), Boulevard of Broken Dreams: why Public Efforts to Boost Entrepreneurship and Venture Capital Have Failed-and What to Do about It, Princeton University Press, Princeton, NJ.

Liebowitz, J. and Suen, C. (2000), "Developing knowledge management metrics for measuring intellectual Capital”, Journal of Intellectual Capital, Vol. 1 No. 1, pp. 54-67.

LiPuma, J.A. (2006), "Independent venture capital, corporate venture capital, and the internationalisation intensity of technology-based portfolio firms", International Entrepreneurship and Management Journal, Vol. 2 No. 2, pp. 245-260.

McNally, K. (1995), "Corporate venture Capital: the financing of technology businesses", International Journal of Entrepreneurial Behavior \& Research, Vol. 1 No. 3, pp. 9-28.

March, J.G. (1991), "Exploration and exploitation in organizational learning", Organization Science, Vol. 2 No. 1, pp. 71-87.

Maula, M. (2007), "Corporate venture Capital as a strategic toll for corporations", in Landström, H. (Ed.), Handbook of Research on Venture Capital, Elgar, Cheltenham, pp. 371-392.

Maula, M. and Murray, G. (2002), "Complementary value-adding roles of corporate venture Capital and independent venture Capital investors", Journal of BioLaw and Business, Vol. 5 No. 2, pp. 29-34.

Maula, M., Autio, E. and Murray, G. (2003), "Prerequisites for the creation of social Capital and subsequent knowledge acquisition in corporate venture Capital", Venture Capital, Vol. 5 No. 2, pp. 117-134.

Maula, M., Autio, E. and Murray, G. (2005), "Corporate venture capitalists and independent venture capitalists: what do they know, who do they know and should entrepreneurs care?", Venture Capital, Vol. 7 No. 1, pp. 3-21. 
Mazzelli, A., De Massis, A., Petruzzelli, A.M., Del Giudice, M. and Khan, Z. (2019), "Behind ambidextrous search: the microfoundations of search in family and non-family firms", Long Range Planning, Vol. 101882, pp. 1-21, doi: 10.1016/j.Irp.2019.05.002.

Mohammad, A.A. (2016), "Changing role of accounting and its systems: a new vision of accounting as knowledge processing systems", International Journal of Managerial and Financial Accounting, Vol. 8 No. 1, pp. 23-38.

Morris, M.H. and Sexton, D.L. (1996), "The concept of entrepreneurial intensity: Implications for company performance", Journal of Business Research, Vol. 36 No. 1, pp. 5-13.

Natalicchio, A., Ardito, L., Savino, T. and Albino, V. (2017), "Managing knowledge assets for open innovation: a systematic literature review", Journal of Knowledge Management, Vol. 21 No. 6, pp. 1362-1383.

Porporato, M. (2013), "Management control systems in joint ventures: literature review and description of three cases", International Journal of Managerial and Financial Accounting, Vol. 5 No. 1, pp. 45-63.

Prieto, I., Revilla, E. and Rodríguez-Prado, B. (2009), "Managing the knowledge paradox in product development", Journal of Knowledge Management, Vol. 13 No. 3, pp. 157-170.

Ramachandran, I., Lengnick-Hall, C. and Badrinarayanan, V. (2019), "Enabling and leveraging ambidexterity: influence of strategic orientations and knowledge stock", Journal of Knowledge Management, Vol. 23 No. 6, pp. 1136-1156.

Rossi, M. (2015), "The role of venture Capital funds in financing innovation in Italy. Constraints and challenges for innovative small firms", International Journal of Globalisation and Small Business, Vol. 7 No. 2, pp. 162-180

Rossi, M. and Martini, E. (2019), "Venture capitalists and value creation. The role of informal investors in the growth of smaller European firms", International Journal of Globalisation and Small Business, Vol. 10 No. 3, pp. 237-243.

Rossi, M., Festa, G., Fiano, F. and Giacobbe, R. (2019b), "To invest or to harvest? - Corporate venture capital ambidexterity for exploiting/exploring innovation in technological business", Business Process Management Journal. pp. 1-25, doi: 10.1108/BPMJ-05-2019-0204.

Rossi, M., Festa, G., Papa, A. and Scorrano, P. (2019a), "Corporate venture capitalists' ambidexterity: myth or truth?", IEEE Transactions on Engineering Management, pp. 1-12, doi: 10.1109/TEM.2019.2903984.

Rossi, M., Festa, G., Solima, L. and Popa, S. (2017), "Financing knowledge-intensive enterprises: evidence from CVCs in the US", The Journal of Technology Transfer, Vol. 42 No. 2, pp. 338-353.

Santoro, G., Thrassou, A., Bresciani, S. and Del Giudice, M. (2019), "Do knowledge management and dynamic capabilities affect ambidextrous entrepreneurial intensity and firms' performance?", IEEE Transactions on Engineering Management, pp. 1-9, doi: 10.1109/TEM.2019.2907874.

Scuotto, V., Arrigo, E., Candelo, E. and Nicotra, M. (2019), "Ambidextrous innovation orientation effected by the digital transformation: a quantitative research on fashion SMEs", Business Process Management Journal, pp. 1-20, doi: 10.1108/BPMJ-03-2019-0135

Scuotto, V., Beatrice, O., Valentina, C., Nicotra, M., Di Gioia, L. and Briamonte, M.F. (2020), "Uncovering the micro-foundations of knowledge sharing in open innovation partnerships: an intention-based perspective of technology transfer", Technological Forecasting and Social Change, Vol. 152 No. 2020, pp. 1-15, doi: 10.1016/j.techfore.2019.119906.

Shaabani, E., Ahmadi, H. and Yazdani, H. (2012), "Do interactions among elements of knowledge management lead to acquiring core competencies?", Business Strategy Series, Vol. 13 No. 6, pp. 307-322.

Soto-Acosta, P., Popa, S. and Martinez-Conesa, I. (2018), "Information technology, knowledge management and environmental dynamism as drivers of innovation ambidexterity: a study in SMEs", Journal of Knowledge Management, Vol. 22 No. 4, pp. 824-849.

Sun, P. (2010), "Five critical knowledge management organizational themes", Journal of Knowledge Management, Vol. 14 No. 4, pp. 507-523.

Vrontis, D., Thrassou, A., Santoro, G. and Papa, A. (2017), "Ambidexterity, external knowledge and performance in knowledge-intensive firms", The Journal of Technology Transfer, Vol. 42 No. 2, pp. 374-388.

Wu, J. and Shanley, M.T. (2009), "Knowledge stock, exploration, and innovation: research on the United States electromedical device industry", Journal of Business Research, Vol. 62 No. 4, pp. 474-483. 
Author affiliations

Matteo Rossi is based at the Department of Law Economics Management and Quantitative Methods, University of Sannio, Benevento, Italy and Wyższa Szkoła Bankowa w Poznaniu WSB University, Poznan, Poland.

Giuseppe Festa is based at the Department of Economics and Statistics, University of Salerno, Fisciano, Italy.

Armando Papa is based at the Faculty of Business and Economics, University of Rome Universitas Mercatorum, Rome, Italy and Higher School of Economics, National Research University, Moscow, Russian Federation.

Ashutosh Kolte is based at the Department of Management Sciences, Savitribai Phule Pune University, Pune, India.

Rossana Piccolo is based at the Department of Economics, University of Campania Luigi Vanvitelli, Capua, Italy.

About the authors

Matteo Rossi is an Associate Professor of Corporate Finance at the University of Sannio, Benevento, Italy, where he received the PhD degree in Management. He is also an Adjunct Professor of Advanced Corporate Finance at LUISS, Rome, Italy. Dr Rossi is the Editor-inChief for the International Journal of Managerial and Financial Accounting.

Giuseppe Festa is an Assistant Professor of Management at the Department of Economics and Statistics of the University of Salerno, Italy, EU. He holds a PhD in Economics and Management of Public Organizations from the University of Salerno, where he is the Scientific Director of the Postgraduate course in Wine Business and the Vice-Director of the Second Level Master's in Management of Healthcare Organizations - Daosan. He is also the Chairman of the Euromed Research Interest Committee on Wine Business. His research interests focus mainly on wine business, information systems and health-care management. Giuseppe Festa is the corresponding author and can be contacted at: gfesta@unisa.it

Armando Papa is an Associate Professor of Management at the School of Economics of the Mercatorum University in Rome, Italy. He received the Postgraduate Master's degree in corporate finance from Istituto IPE, Naples, Italy, and the PhD degree in management from the University of Naples "Federico II," Naples, Italy. He is an Associate Editor for Journal of Knowledge Economy (Springer) and an Editorial Assistant for Journal of Knowledge Management (Emerald).

Ashutosh Kolte is an Associate Professor of Finance and Economics at the Department of Management Sciences (PUMBA), Savitribai Phule Pune University, Pune, India. He was Postdoctoral Fellow at University of Sannio, Italy. He has research interest in the area of Corporate Finance, Economics and Financial Management. He sits in the editorial board of International Journal of Globalisation and Small Business and acts as referee for many international journals.

Rossana Piccolo is Research Fellow at the Department of Economics of the University of Campania - Luigi Vanvitelli. She holds a European PhD in Entrepreneurship and Innovation, with specialization on Behavioral Finance in the credit sector. She received a Master's Degree in Finance and Markets from the Second University of Naples, Italy, with specialization on Advanced Corporate Finance, in 2012. Her studies and research interests are focused around the behavioral aspects of Innovation, Management and Finance. She is currently involved in research studies on soft dimension of technological innovation and the role of knowledge management in fintech. She is also involved in several peer review processes for international journals.

For instructions on how to order reprints of this article, please visit our website:

www.emeraldgrouppublishing.com/licensing/reprints.htm

Or contact us for further details: permissions@emeraldinsight.com 